\title{
King Saul's mustering of all Israel (1 Sm 11:6-7): An idealised leadership
}

\begin{abstract}
Author:
Jeong Bong Kim ${ }^{1,2}$

Affiliations:

${ }^{1}$ Research associate,

Department of Old

Testament Studies, University

of Pretoria, South Africa

${ }^{2}$ Korea Baptist Theological

University, Korea

Correspondence to:

Jeong Bong Kim

Email:

kimjeongbong@yahoo.com

Postal address:

410-101 Expo Apt. Jeonmindong Yuseong-gu Daejeon Korea (305-762)

\section{Dates:}

Received: 17 June 2011

Accepted: 27 Sept. 2011

Published: 06 Dec. 2011

How to cite this article: Kim, J.B., 2011, 'King Saul's mustering of all Israel (1 Sm 11:6-7): An idealised leadership', Verbum et Ecclesia 32(1), Art. \#557, 7 pages. http://dx.doi. org/10.402/ve.v32i1.557

\section{Note:}

This article is slightly revised from the Ph.D thesis completed under the supervision of Prof. D.J. Human, submitted to the Department of Old Testament Studies in the Faculty of Theology of the University of Pretoria in 2008.
\end{abstract}

(C) 2011. The Authors. Licensee: AOSIS OpenJournals. This work is licensed under the Creative Commons Attribution License.
1 Samuel 11:6-7 report the beginning of Saul's public life and demonstrate his leadership over Israel. However, the verses do not clearly indicate his role in the specific events related in verses 1-11. This article clarifies Saul's idealised kingly leadership by examining some of the literary-critical issues of 1 Samuel 11:1-11 in their broader context. Saul's leadership was then considered against its larger ancient Near Eastern context. The article aimed to show that both Saul's religious authority and also his political ability were welcomed in his emerging kingship.

\section{Introduction}

Saul's mustering of all Israel as told in 1 Samuel 11:6-7 highlights the empowered leadership of Saul that was absolute and critical in the impending national crisis with the Ammonites. These verses show that the leadership of Saul was highly authoritative and on this occasion highly successful, causing the people of Israel to respond as one in defeating their enemy. The literary context of the event (1 Sm 8-12; cf. 1 Sm 8:5; 11:12-15; 12:12-13) shows us that the response to Saul indicated the people welcomed the kingship of Saul (cf Van Seters 2009:287).

However, in this specific event there is no implication that his leadership demonstrates kingship. 1 Samuel 11:1-11 does not portray Saul as a royal figure and there is no indication that, in this national crisis, Israel was aware of Saul as such. The writer is seemingly not interested in introducing Saul as a royal figure, but rather emphasises his heroic leadership, empowered by 'the spirit of God'.

In this article the contextual contradictions in interpreting the nature of the Saul's leadership focus on a proper textual understanding of 1 Samuel 11:6-7 and its place in the broader context of 1 Samuel 8-12. Specifically the focus is on an understanding of Saul's role in the biblical context as well as in its macro-context. I will argue that the leadership of Saul, as portrayed in 1 Samuel 11:67 , is idealised and that his kingship is presented not only in relation to his political leadership but also in relation to his religious authority.

I discuss first the critical textual issues arising out of 1 Samuel 11:1-11, referring to the three major textual traditions behind the biblical text, that is, the MT, the LXX, and 4QSama. This provides a textual basis for a discussion in the following section on the role of Saul, not as a judge, but as a military leader and king. The contention is that Saul's religious authority guaranteed his kingship. Within the textual and contextual understanding of Saul's leadership, I clarify that his appearance was not like that of a judge, but rather as a military leader and king, empowered by 'the spirit of God'. The discussion focuses on the religious qualities of his leadership. I argue that the prophetic connections of Saul provide a religious background for his kingship. My aim is to explain that the people of the ancient Near East saw his prophetic qualities as a sign of an idealised kingship. In conclusion, the leadership of Saul is presented as the ideal of kingship in 1 Samuel 11:6-7.

\section{The text critical issue}

Different textual traditions give rise to questions regarding the origin of 1 Samuel 11:1-11. The longer account of the event in 4QSam ${ }^{a}$ provides a reason for Nahash's campaign against Jabesh (Gilead), explaining that the attack of Nahash on Gad and Reuben was the preliminary cause of the events described in 1 Samuel 11:1-11. Unlike the Qumran text, the MT is silent regarding the precipitating reason for the attack. On the other hand, the LXX obscurely introduces a chronological

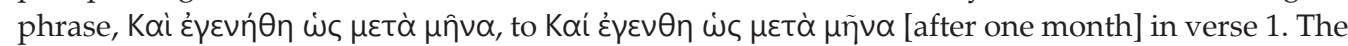
phrase is ambiguous. It is not clear whether it refers to the previous event described in 1 Samuel 10:17-27 or to 1 Samuel 10:1-16. Another possibility is that it refers to Nahash's attack on Gad 
and Reuben, as reported in 4QSama ${ }^{\mathrm{a}}$. The three diverse texts testify to different textual traditions. This textual discrepancy demands attention.

Tov reads the text of $4 \mathrm{QSam}{ }^{\mathrm{a}}$, which is reconstructed by Cross, as follows:

6 [And Na]hash, king of the children of Ammon, sorely oppressed the children of Gad and the children of Reuben, and he gouged out a[11] their 7 right eyes and struck ter[ror and dread] in Israel. There was not left one among the children of Israel bey[ond the] 8 [Jordan who]se right eye was no[t go]uged out by Naha[sh king] of the children of Ammon; except seven thousand en 9 [fled from] the children of Ammon and entered [J]abesh-Gilead. (above the line: About a month later, Nahash the Ammonite went up and besieged Jabesh-[Gilead]) and all the men of Jabesh said to Nahash 10 [the Ammonite, 'Make] with [us a covenant and we shall become your subjects.'] Nahash [the Ammonite said t]o [th]em, ['After this fashion will] I make [a covenant with you]...

(Tov 2001:342-343)

As seen in this construction, 4QSam ${ }^{a}$ reports in detail that the attack on Jabesh (Gilead) is part of the attack on Gad and Reuben by Nahash. Its additional explication of the attack led some scholars to believe that 4 QSam ${ }^{a}$ preserved the more authentic historical account (see Tov 2001:342-344; McCarter 1980:199). The textual reading of 4QSama; however, has been critically challenged as a gloss added later to explain the reason for the attack of Nahash (Barthélemy 1982:162-163; Rofé 1982:129-33). Others prefer the LXX text (Peterson 1999:67; Parry 1996:106-125). There is a striking similarity between the text of LXX and 4QSam ${ }^{\mathrm{a}}$, which contrasts with a reading of the MT. The Vorlage of both the MT and the LXX accords, in most cases, with that of 4QSama (Orlinsky 1975:113-114).

Although the three textual readings differ in some areas, the readings all share the same, or a similar, textual tradition. Eves (1982:325) contended four traditions for 1 Samuel 10:2711:2, namely 4QSam ${ }^{\mathrm{a}}$ and Josephus; LXX' ; Origen's Hexapla, and the Old Latin, boc2e2. His contention is that the traditions of $4 \mathrm{QSam}{ }^{\mathrm{a}}$ differ from readings from Masoretic, Septuagint, or Samaritan Pentateuch traditions. Thus, state Eves, 4QSam ${ }^{a}$ 'must be recognized as additional, independent witnesses to the textual situation in Palestine'. His conclusion is that the additions in the Qumran text only served to provide the aetiology of the event. It is difficult to insist that any one textual reading preserves the more authentic historical account. A reading of 4 QSam ${ }^{a}$ probably shows additional information added, as was the practice of the Qumran community, as a midrashic interpretation (Edelman 1991:60).

The focus of the text critical issue presented here is not to reconstruct the original text, but to understand the different textual traditions that probably originated from an Urtext. A further assumption is that the different traditions of 1 Samuel 11 evince that each reading had its own literary value in its own historical context. Although the additions of 4QSam ${ }^{\mathrm{a}}$ possibly provide a background to the events of 1 Samuel 11:1-11 (MT), they are not significant to the prophetic context of the event, which is the central argument of this paper as it looks at Saul's mustering of his people. Thus, the tradition of the MT is retained in this article.

\section{As king, Saul was a military leader}

A significant literary-critical observation comes from a conversation between Nahash and the elders of Israel. Upon Nahash's challenge to all Israel (1 Sm 11:2), the elders request time to find a deliverer. The narrator indicates that Nahash did not know of any royal figure amongst the Israelites. Neither did the elders express explicitly whether they would receive help from the king of Israel. Their expression was ambiguous and focused on the term, 'a deliverer'.

If indeed the biblical narrative in 1 Samuel 10:17-27 preceded the event in 1 Samuel 11, which was the chronological intention of the final redactor, why then did they not respond to Nahash by saying that they would ask their king to rescue them from Nahash the Ammonite? The conversation between Nahash and the elders showed that both Nahash and the elders seemingly did not anticipate any particular religious or political leader, such as Samuel or Saul to save them. Significant questions arise about the presence or absence of Saul and Samuel in the war that followed. This contextual inconsistency poses a textual problem regarding the position of 1 Samuel 11:1-11 in the macro structure of the narrative.

'Deliverer' was the typical term used for a judge in the period of the judges ( $\operatorname{Jdg} 3: 9,15 ; 6: 36 ; 12: 3)$. If the elders meant 'a judge,' then the critical question arises why they did not go to Samuel directly. He was a judge who could lead them out of the disaster, if indeed his leadership as judge was still guaranteed by Yahweh, as it had been in 1 Samuel 7:7-14. 1 Samuel 7:15 states that Samuel judged Israel throughout his life. Samuel's death is only recorded in 1 Samuel 25:1. The death of Samuel came only after the anointing of David as successor to Saul, and this event provided the political and religious background for David to rise against Saul. Thus, in the crisis of Jabesh-Gilead it is legitimate to expect the elders to turn to Samuel for military leadership in delivering them from their enemies.

1 Samuel 11:1-11 suggests that Samuel's role had already been lessened as a political leader, as compared to 1 Samuel 7:7-14, where Samuel is presented as being a religious and political leader throughout his life time (cf Vriezen \& Van der Woude 2005:293-294). This conflict raises a textual question: why did the final redactor underscore Samuel as having such a highly respected role in the narrative of Saul's mustering of the people (1 Sm 11:7)? The broader context (1 Sm 16:2) probably provides an answer in its depiction of the relationships between Saul, David and Samuel.

It remains what the elders intended by the term, 'deliverer', both as regards its political meaning and in the broader context of the event. This critical issue makes it difficult to discern from 1 Samuel 11:1-11 whether Saul was seen as a judge or a king. A better perspective on this issue may be gained once we see the question in the broader context 


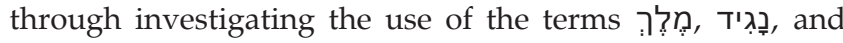

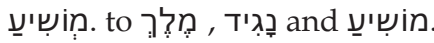

- The people requested a מִלְר [king] (1 Sm 8:5).

- Samuel anointed Saul as a בָגְיריד [military leader] (1 Sm 10:1)

- The people acclaimed Saul as a מִלְך [king] but Samuel announced him as chosen by Yahweh (1 Sm 10:24).

- The elders of Jabesh (Gilead) implore to have a chance to find a מוֹשִיעַ [deliverer] (1 Sm 11:3).

- All the people made Saul king of Israel (1) (1 Sm 11:15).

This essay poses the following critical questions: if Saul's kingship is denied in 1 Samuel 11:1-11, how can the current positioning of the text in 1 Samuel 8-1 Samuel 12 be explained? How can Saul be crowned king of Israel right after repelling the threat of Ammonites where he played the role of a judge? The role in which Saul is depicted in 1 Samuel 11:1-11 is unclear. As king, was he a judge or a military leader?

Ackerman (1991:12-13) suggests that 1 Samuel 11:1-11 describes Saul as a judge (See also Jobling 1998:66). The description of Saul, according to him, evinces how Yahweh chose him as the leader, 'YHWH's nagid' and not as a king, as he is chosen in 1 Samuel 10:17-27. Ackerman considered that evidence of 'the spirit of God' is the most striking characteristic of the judges. The so-called major judges were empowered by 'the spirit of Yahweh'. It marked them as Yahweh's representative to expel the enemies. They provided charismatic leadership (Jdg 3:10; 11:29; 13:25; 14:6, $19 ; 15: 14)$. As deliverers, they demonstrated that Yahweh is the source of their power. However, the strikingly different context of the event as described in 1 Samuel 11 and the context as described in Judges is most noticeable with regard to Saul's prophetic qualities. In 1 Samuel 10:10, Saul prophesies amongst the band of prophets, anointed with 'the spirit of God'. In 1 Samuel 11 the coming of 'the spirit of God' seemingly results from the prophecy of Samuel in 1 Samuel 10:7. The prophetic characteristics described in 1 Samuel 11:1-11 bring a critical indication of a different literary and historical interpretation of the event. Kasari (2009:69-70) attempted to describe the role of Saul through the textual examination of 1 Samuel 11 and 15. She showed strong textual connections for 1 Samuel 10:27 (LXX)-11:11, 15 and 1 Samuel 15:4-5, 7-8, 12 and 32-34, in relation to both events and ideas. In drawing her conclusions, she contrasted Saul's mustering of the people (1 Sm 11:8 and 15:4), the surprise attack (1 Sm 11:11a and 15:5) and the flight of the enemy (1 Sm 11:11b and 15:7), the importance of Gilgal (1 Sm 11:15 and 15:12,33), and the absence of Samuel in both chapters. She suggests that the two accounts were originally together, depicting Saul as a 'saviour-judge'. However, they lacked a proper explanation of the coming of 'the spirit of God' (1 Sm 11:6) as the typical sign of a judge. But this connection cannot by itself provide any irrefutable evidence for the role of Saul.

Miller (1974:157-174) reconstructed the sequence of Saul's role as leader based on an understanding of Saul's charismatic role as portrayed in 1 Samuel 9:1-10:16, 13:2-14:46, 10:26-
11:15 and 16:1-5. Miller (1974:165-171) suggested that the account of 1 Samuel 11:1-11 was a late tradition that attested to a strong military leadership of Saul having been established in the early stages of his kingship, because without that Saul could not have summoned the people of Israel as effectively. Miller (1974:170) saw Saul, the king, as a military leader who had established his kingship through the event described in 1 Samuel 11 (Ahlström 1993:447). The thrust of Miller's reconstruction is to highlight the political authority of Saul.

Based on a comparative analysis of ancient Near Eastern literature, Edelman (1991:30-34) proposed a tripartite pattern of the kingship installation ceremony described in 1 Samuel 8-12 that consisted of designation, testing and coronation. Edelman (1984:194) contended that Saul was the 'elect-king' until he had proved his ability, as occurred in 1 Samuel 11, she explained the events of Saul's coronation in the context of the historical narrative. However, it is hard to say that she succeeded in explaining the contextual relationship of 1 Samuel 10:17-27 with 1 Samuel 9:1-10:16 and 1 Samuel 11:1-11 as the event of 1 Samuel 10:17-27 is not contextually related to 1 Samuel 9:1-10:16 or to 1 Samuel 11:1-11. Also her sequential reading of the narrative does not provide any legitimate reason why the two groups who had been with Saul during the meeting in the high place (1 Sm 9:22-24) and during the prophesying of Saul (1 Sm 10:9-13). Above all the reading needs to give the theological reason why confirmation was needed when the 'elect-king' was designated, Edelman's proposal does seem arbitrary, as it fails to explain why Saul would need to go through a stage of testing for his divinely sanctioned kingship.

It appears certain that the broader context of 1 Samuel 11:1-11 refer to kingship in Israel. In the context, the idealised leadership of Saul, as presented, is distinctive from institutionalised kingship (1 Sm 8; 10:17-27; 11:12-15; 12). Saul's leadership is emphasised for its religious dimension, as seen in his empowerment through the spirit of God (1 Sm $10: 10 ; 11: 6)$ and in his connection with the ecstatic prophets in 1 Samuel 10:10 (cf 1 Sm 9:22-24).

Three conflicts arising between Saul and Samuel related to the religious position of Saul's leadership. These were, firstly, Saul's performing the role of priest before the battle with the Philistines (1 Sm 13:9-14), secondly, his disobedience regarding the divine punishment imposed on Amalek (1 Sm 15:10-35), and finally, his engagement with the medium at En-dor (1 Sm 28:3-25). Falk (1994:50) saw that these conflicts originated from 'the ideological basis for a differentiation between "divine matters" and "matters of the king", which sometimes led to clashes between them'. These three areas of conflict show that the clashes between Saul and Samuel involved their different positions in relation to spiritual matters in the kingship. Saul considered the 'divine matters' of the priest to be part of the 'matters of the king.' In summation, the broader context of Saul's leadership shows that his leadership was like a kingship, also expressed as religious authority. 


\section{Religious background of the kingship}

1 Samuel 11:6 tells that the origin of Saul's leadership was his empowerment by the 'spirit of God', an experience that turned Saul into a different man. This decisive phenomenon enabled the people to believe that Saul was the divinely sanctioned leader over them. Being transformed into a different man by the 'spirit of God' was significant in that it kept in focus the religious background of Saul as his kingship emerged (cf

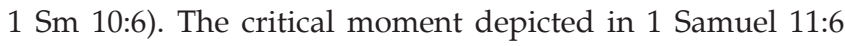
reflects the fulfilment of the prophecy in 1 Samuel 10:7.

Many critical scholars contend that 1 Samuel 10:8 is connected with the occasion of 1 Samuel 13 in Gilgal (Long 1996: 417-418; Eslinger 1985:324-325). Long (1996:417-418) saw the commands of 1 Samuel 10:7-8 as 'complementary instructions'. What Saul was commissioned to do in 1 Samuel 10:7 is related to 1 Samuel 10:5, which mentions the Philistine garrison encamped on the hill of God. Long considered the specific mention of the Philistine garrison to have a particular connection with God's appointment of Saul (1 Sm 9:16) and Samuel's command to Saul (1 Sm 10:7). Jonathan's attack on the Philistines after Saul had waited seven days in Gilgal shows a similar relationship between the appointment and Samuel's command to Saul in 1 Samuel 9:16 and 10:7-8. Long (1996:418-420) tried to resolve the large time gap between 1 Samuel 10:7-8 and 1 Samuel 13 with a literary device, a gapping that is supposedly 'legitimated by the text'. Kaiser (1998:210) also argued that the context of 1 Samuel 10:7 suggested a Philistine presence in Gibeah, not that of the Ammonites, strongly denying the possibility of the prophetic connection of 1 Samuel 11:6.

However, some critical scholars ignore the fact that 1 Samuel 10:7 is not contextually connected with the verse that follows it. McCarter (1980:183) suggests that 1 Samuel 10:8 is rather a redactional insertion that legitimises the fall of Saul in the Gilgal event (1 Sm 13). The command in 1 Samuel 10:8 is peculiar in the full context of 1 Samuel 10:1-16 (cf Richter 1970:19).

If the command in 1 Samuel 10:8 anticipates the event in 1 Samuel 13, the connection brings about a highly complicated textual issue. In 1 Samuel 10:1-16 Saul has not yet been presented in public as a king. The absence of recognition for a royal figure in the text departs critically from the implications of 1 Samuel 13 that Saul has already established his kingship amongst the people. Saul is king of Israel in 1 Samuel 13 whereas he is not yet a public royal figure in 1 Samuel 10:8.

Another question can be asked at this point: if 1 Samuel 10:8 relates to 1 Samuel 13, why then did the people of Israel not acclaim Saul as the king right after the event described in 1 Samuel 13? Instead, according to 1 Samuel 11:15, they did it after Saul defeated the Ammonites. The Philistine garrison (1 Sm 10:5) probably stood out for indicating where the hill of God (high place) was located. It was located in Geba not in the Gibeah of Saul (Kitchen 2003:97; also see 1 Sm 13:3). This is closely related to the high place to which Saul was directed by Samuel, where he would find a prophetic band and his uncle (1 Sm 10:1-16) or it is simply a secondary addition along with Samuel's instructions (1 Sm 10:8) for the Gilgal events (1 Sm 13) (McCarter 1980:182)?

A further critical issue regards the chronological order (Klein 1983:123-124; McCarter 1980:228): in chapter 10 of 1 Samuel Saul is a young man who is looking for his father's lost ass, but in chapter 13 he is king whose son is a prince, Jonathan. Thus, for contextual reasons it is unlikely that 1 Samuel 10:8 refers to 1 Samuel 13.

The prophecy of 1 Samuel 10:7 is fulfilled in 1 Samuel 11:6: in 1 Samuel 10:6 Samuel prophecies that Saul will be empowered by 'the spirit of the Lord'. In part fulfilment of the prophecy Saul is empowered with 'the spirit' and in 1 Samuel 10:10 begins prophesying. In 1 Samuel 10:11 we learn that the people witnessed Saul's ecstatic prophecy. As a result, Saul was identified as a prophet amongst the bands of ecstatic prophets.

The prophetic activity of Saul caused some of the watching people to have doubts. Some of them did not want to acknowledge Saul's status as a prophet. On the other hand, they could not avoid witnessing the dramatic change of character in Saul (1 Sm 10:11-12). Hendel (1995:188) points out that a prophet should have either a personal experience of a calling as a prophet, or the recognition of his prophetic calling by others. In 1 Samuel 10:11-12 Saul was recognised as a prophet amongst a prophetic band because of his prophetic activity. Although the people had difficulty recognising him as a prophet, the people refer to Saul's prophesying more in a positive way than in a negative way (Gunn 1980:63).

To the passers-by in the narrative, the prophesying of Saul was undoubtedly seen as part of a prophetic scene $(1 \mathrm{Sm}$ 10:12). The man reported Saul's existence amongst the band of ecstatic prophets. His inquiry 'Who is their father?' was natural in the situation. Saul's identity as an ecstatic prophet was safeguarded by his being empowered by the 'spirit of God' to prophesy in ecstasy (Atwell 2004:152; 1 Sm 10:10).

The prophetic context communicated in 1 Samuel 10:1-16 stands in continuity with 1 Samuel 9:1-27: In 1 Samuel 9:15 Saul appears in town confirming the word of Yahweh. Samuel, as the seer, receives the word and communicates it to Saul (1 Sm 9:27). In the context it is highly significant to observe that the setting of the meeting is the high place. In 1 Samuel 9:14 and 9:19 Samuel has shown his own close relationship with the high place. Specifically, in 1 Samuel 9:19, Samuel introduced himself to Saul as 'the seer', asking Saul to go up to the high place to meet him there for a party with all who were invited. A question arises about the identity of the guests. Why did the narrator not provide their identity (1 Sm 9:22)? Does the non-identification mean the event was unimportant? Why did Samuel prepare the meeting for Saul as well as for the people (1 Sm 9:22-24)? 
Why did Samuel prepare the meeting at the time of the sacrifice when all the people would come (1 Sm 9:12-13)? All these questions suggest that the occasion at the high place was indeed significant.

An answer to these questions is found in the biblical text, as well as an indication as to the meaning of the people's presence. In 1 Samuel 9:12 some girls answer the question of Saul and his servant, saying that the seer is there to bring a sacrifice for the people gathered at the high place. They speak about the matter with confidence and therefore the people mentioned by the girls are most probably regular worshippers at these sacrifices, and not people specifically invited for the occasion. The general description of the people indicates that they were not elders or socially highly positioned people. It seems then that Samuel invited ordinary people and that those invited were ready to meet Saul in secret, in the public place. This suggests a 'communal celebration' of the sacrifice to Yahweh. Thus, the meeting could be kept secret, as it seemed nothing more than a customary gathering. However, the intentionality of the meeting at the sacrifice is revealed by Samuel's remark that he invited people (1 Sm 9:24).

Samuel clarified to Saul that he invited the people (1 Sm 9:24). As suggested by Matthews (2001:44), the design of the meeting (1 Sm 9:22-24) looked private. Outwardly no one would realise that the meeting triggered the emergence of a political and social revolution in Israel, namely the monarchy. However, the narrator informed his readers that it was planned by Samuel to introduce Saul to the invited people, thereby motivating him to be anointed as nagid (1 Sm 10:1).

Samuel's invitation hints at the fact that a religious rather than a political concern motivated him. In keeping with the political protocol, Samuel's special treatment of Saul was no surprise to the invited people. If they had been elders, or other socially highly positioned people, they might have been surprised to see the special treatment given to Saul before themselves, as, in the text, he was a young man and a stranger ( $\mathrm{cf} 1 \mathrm{Sm}$ 9:5-10). The text implies that the invited people were aware of what was about to happen when Samuel invited them. Although the biblical text does not indicate the significance of this meeting, it appears that Samuel anticipated the meeting with special preparations for Saul. It seems likely that the special atmosphere of the meeting created by Samuel indicates a 'pre-coronation meal' (Firth 2009:124).

A special relationship between Samuel and the invited people is conveyed in the use of קראתִ

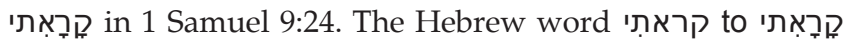
[I have invited] is reminiscent of the story of Samuel's calling in 1 Samuel 3:5-6. The story in 1 Samuel 3 indicates that the Lord chose Samuel as a prophet of the Lord who listened to his calling when Eli could not hear it. In 1 Samuel 3:4 the Lord called Samuel, and he replied, 'Here I am'. 1 Samuel 3:19-20 tells that Samuel was confirmed as a prophet of the Lord, because the Lord was with him. In 1 Samuel 9:24, however, Samuel said, 'I did call the people' in regard to the reception of Saul. Samuel had listened to God's calling (1 Sm 3:5-6). In 1 Samuel 9:22-24 Samuel called specific people in advance to an explicit occasion. The moment was significant because Saul was presented in public to these invited people (cf Miscall 1986:58).

The occasion is also analogous to the encounter of Saul with the prophetic band from the high place (1 Sm 10:5, 10). The public engagement of Saul implies that Saul was publicly identified with the prophetic figures. Eslinger (1985:313) explained this by saying that it was Samuel's intention to anoint Saul secretly (1 Sm 10:1). However, one should be cautious before saying that the political intention of the meal was designed to be concealed from the invited people.

The people were united by the invitation of Samuel and witnessed Samuel's special treatment of Saul (1 Sm 9:2224). Samuel's individual treatment of Saul was expressed publically in front of the invited people. It is unclear whether Samuel explained his intention to those invited to the banquet. The text does not clearly indicate whether the invited people knew why they were invited or not. If we consider that the people were simply invited to the reception of the nagid, the meeting was unnecessary for Saul as well as for Samuel who anointed him later in secret. The relation of 1 Samuel 3:5-6 within the contextual situation of 1 Samuel 9:1-10:16 suggests a prophetic connection between Samuel and the invited people, particularly within a political context. Thus, a logical conjecture follows: the invited people were part of the prophetic groups that Samuel organised to introduce the kingship of Saul to the people of Israel and were later incorporated into Saul's regime as Samuel departed from Saul to Ramah. Further, they were primarily responsible for preserving the traditions of 1 Samuel 9:1-10:16 and 11:1-11, for legitimising the leadership of Saul and for idealising Saul as a divinely sanctioned leader and king in Israel.

If the aforementioned conjecture is correct, the meeting suggests that it was a significant political convocation that formed part of Saul's emergence as king. The meeting marks Saul's appearance at a high place under Samuel's authority.

The presence of Saul was probably planned by Samuel to endorse his choice of Saul to the prophetic group. Samuel showed his hospitality both to them and to Saul (1 Sm 9:2224). Thus, Samuel wished to prepare them to understand that the time for a monarchy in Israel had come and therefore began to group his prophetic disciples in the high place.

This denoted the beginning of their motivation for a political movement that would actualise their religious beliefs in support of the monarchy. The political manner of the meeting implies that at the time there were several prophetic groups in the high places (cf 1 Sm 10:14-16). Accordingly, it is natural to see a certain tension between their respective prophetic activities. Samuel's mobilisation of the prophets 
plays a critical role in the emergence of the kingship. The meeting signifies that Saul was amongst the prophets. Saul, having been brought to the prophetic group in the precoronation meeting prepared by Samuel (1 Sm 9:22-24), was then anointed as nagid by Samuel in secret (1 Sm 10:1). He was shown publically to be a prophet as he joined a prophetic group from the high place and then demonstrated that he had become a different man (1 Sm 10:9-13). Now Saul showed that he was a prophet upon whom 'the spirit of the Lord' had come (1 Sm 10:10).

In 1 Samuel 11:7 the divinely sanctioned leadership of Saul

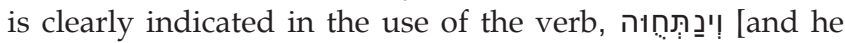
cut them in pieces]. The basic meaning of the root חת is 'to cut something in pieces' for sacrifices. The root only appears in the piel form, mainly to indicate the cultic activity in the sacrifice, as shown in Leviticus 1:6 and 12 where it tells about the duty of the priests in the sacrifice (Driver 1913:86).

It is critical to observe the action in a cultic context because the manner in which Saul mustered the people reflected a cultic activity. For instance, in 1 Kings 18:23, Elijah asked the

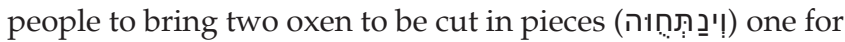
Yahweh and one for Baal, to prove which one is God. It was a sacrifice.

Another example comes from Judges 19:29. In this verse an anonymous Levite challenged the tribes of Israel to come out to punish the Benjaminites, as he cut the corpse of his

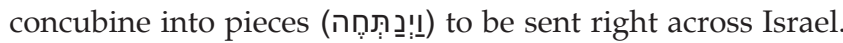
His concubine was a Bethlehemite. On the way home from Bethlehem, the Levite was threatened with a serious sexual attack in Gibeah (Jdg 19:22). As a result, he owed his life to his concubine (Jdg 19:27). Once he returned home, he cut the corpse of the concubine into pieces and sent them across Israel to muster military action to punish the people of Benjamin. On the one hand, his action shows infidelity and wilful sin as a priest (Wenham 2000:67-68). On the other hand, it illustrates that he was well practiced in the offering of sacrifices. He was a priest. It is significant to note that the Levite was a priest in the house of the Lord, as his priesthood provides a cultic background to the narrative.

The analogy suggests a probable cultic context for Saul. A likely cultic tone of the action is seen in the immediateness of Saul's mustering of the people. Saul immediately cut up the oxen with him on the way home, as 'the spirit of God'

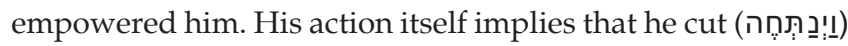
it with a knife. The implication of describing the instrument used to cut it focuses on the immediateness of the action. A probable conjecture is that the narrator was indicating that Saul was practiced and well prepared in the killing of sacrificial animals.

The religious characteristics of Saul as king were to be expected of a king in Israel in the ancient Near Eastern background of the time. 1 Samuel 8:5 indicated the model for the kingship they desired (cf Schniedewind 1999:24). The people desired to have a king just like that of the surrounding nations, although the request of the people for a king was interpreted as a 'fresh act of infidelity' to God (Frolov 2004:156) in the eyes of Samuel (1 Sm 8:6; 12:17). Amit (1999:44-45) illustrates the marked influence of the surrounding ancient cultures on kingship in the book of Samuel: divine sanction for the election and anointing by God; a unique relationship between God and the king and his offspring; divine wisdom for the king regarding justice in the monarchy and the religious place and position of the king in religious rituals. Out of this illustration she emphasised the clear link between the king and the deity. As confessed by David (1 Sm 26:9), the anointing of Saul was specially sanctioned. Also, kingship as described in the book of Samuel stressed the possible role of the priest in religious expression (2 Sm 8:18b). The prophetic characteristics of Saul, anointed with 'the spirit of God', possibly endorsed the religious authority of his kingship and was something that the people would have anticipated as through his divine knowledge he would be able to rescue and protect them.

Understanding of kingship in the ancient Near East provides a credible context for the type of kingship portrayed in the book of Samuel. In ancient Egypt the king was identified with the divine nature of the gods (Baines 1998:23-24; Smith 1997:83). The concept of kingship justified the belief that the king was either a god amongst gods or a priest of priests. The kingship in Mesopotamia also was identified with a divinely sanctioned kingship (Leick 2003:80; Pollock 1999:191). But the king of Mesopotamia was rather a representative of the gods, as symbolised in the term 'shepherd.' (Lambert 1998:57; Van de Mieroop 1997:119). In Canaan the kingship was confirmed as a close relationship between king and priests (Day 1998:74-75). Kingship in Canaan was seen as priestly kingship (KAI 13.1, 2; KTU 1.14).

The religious background to the account of Saul, as discussed earlier in this article, demonstrates that the leadership expressed through Saul's mustering of the people fitted well with the kind of leadership people expected to have from a king, as it was similar to the leadership that other nations had. In 1 Samuel 8:5, the people expected to have a king who was like that of all the other nations, who could protect them from the enemies, and who could represent them to Yahweh in the cultic practices (cf Ahlström 1993:430). Both the political ability (cf Levinson 2001:517) and the cultic status were needed to unite Israel.

\section{Conclusion}

1 Samuel 11:6-7 describes the origins of the divine leadership of Saul and how this leadership functioned. The narrator shows that, once empowered by 'the spirit of God', Saul magnificently demonstrated his leadership by mustering the tribes of Israel to fight as a unit. This depiction of Saul's leadership distinguished him from the judges. These verses successfully describe that Saul's authority as leader of Israel was divinely sanctioned by his anointing with 'the spirit of God'. 
As a result of these qualities in Saul's leadership, his mustering of the people was successful. The success was therefore the direct result of his divinely sanctioned leadership, which had been implied in the secret meeting with the prophetic group at the high place (1 Sm 9:22-24). The people actualised the leadership of Saul by their immediate response in becoming his army. Before demonstrating his leadership, Saul was just a part of the people ( $\mathrm{cf} 1 \mathrm{Sm}$ 10:12). In the very beginning of Saul's public appearance he was seen as a traditional prophet but his empowerment with 'the spirit of God' was interpreted as divine sanction endorsing his leadership. The people now came to Saul as their king. The unity of Israel in fighting against the enemy was what they expected of his kingship (cf 1 Sm 8:20).

1 Samuel 11:6-7 idealises the political leadership of Saul as religious. The concept of the leadership presented in 1 Samuel 11:6-7 idealises Saul as the divinely sanctioned leader and king. The mustering of the people by Saul (1 Sm 11:6-7) confirms his royal leadership. His leadership is also attested to in the context of the ancient Near East and its expectations of kingship.

I argue that the leadership of Saul was not only based on his political capability but also on his religious authority. Israel came out 'after Saul'. Israel saw the right moment that she had been anticipating from her expectations of kingship, like that of all the surrounding nations. All of Israel was united under the political and religious leadership of one man, Saul, who was sanctified by Yahweh. The emergence of the kingship of Saul in Israel arose out of the recognition of the people that Saul would combine political and religious leadership qualities in protecting them.

\section{Acknowledgements \\ Author competing interests}

The author declares that he has no financial or personal relationship(s), which may have inappropriately influenced him in writing this paper.

\section{References}

Ackerman, J.S., 1991, 'Who can stand before YHWH, this holy God? A reading of 1 Samuel 1-15', Prooftexts 11, Fall 1991, 1-24.

Ahlström, G.W., 1993, The history of ancient Palestine from the Paleolithic period to Alexander's conquest: with a contribution by Gary $O$. Rollefson and edited by Diana Edelman, JSOT, suppl. ser. 146.

Amit, Y., 1999, History and ideology: An introduction to historiography in the Hebrew Bible, Sheffield Academic Press, Sheffield.

Atwell, J.E., 2004, The sources of the Old Testament: A guide to the religious thought of the Hebrew Bible, T \& T Clark, London.

Baines, J. 1998, 'Ancient Egyptian kingship: Official forms, rhetoric, context', Day, 16-53.

Barthélemy, D., 1982, Critique textuelle de l'Ancien Testament: Josué, Judges, Ruth, Samuel, Rois, Chroniques, Esdras, Néhémie, Esther. Rapport final du comité pour l'analyse textuelle de I'A.T (OBO 50/1). Göttingen: hébreu institute par l'Alliance Biblique Universelle.

Day, J. (ed.), 1998, King and messiah in Israel and the ancient near East: proceedings of the Oxford Old Testament seminar, JSOT, suppl. ser. 270.
Dietrich, M., Loretz, O. \& Sanmartín, J. (KTU) 1976, Die Keilalphabetischen Texte aus Ugarit, 1: Transkription (AOAT 24/1). Kevelaer and Neukirchen-Vluyn: Neukirchener Verlag

Donner, H. \& Röllig, W. (KAI) 1962-1964, Kanaanäische und aramäische Inschriften, Harrassowitz, Wiesbaden

Driver, S.R., 1913, An introduction to the literature of the Old Testament, 9th edn., T \& T Clark, Edinburgh.

Edelman, D.V., 1984, 'Saul's rescue of Jabesh-Gilead (1 Samuel 11:1-11): sorting story from history', ZAW 96, 195-209.

Edelman, D.V., 1991, King Saul in the historiography of Judah. Sheffield Academic Press, Sheffield.

Eslinger, L.M., 1985, Kingship of God in crisis: a close reading of 1 Samuel 1-12, Almond, Decatur.

Eves, T., 1982. One Ammonites invasion or two? 1 Sam 10:27-11:2 in the light of 4QSamª, WTJ 44, 308-326.

Falk, Z.W., 1994, 'Religion and state in ancient Israel', in H.G. Reventlow, Y. Hoffman \& B. Uffenheimer (eds.), Politics and theopolitics in the Bible and postbiblica literature, JSOT, suppl. ser. 171.

Firth, D.G., 2009, 1 \& 2 Samuel (AOTC 8), Apollos, Nottingham.

Frolov, S., 2004, The turn of the cycle: 1 Samuel 1-8 in synchronic and diachronic perspectives (BZAW 342), Walter de Gruyster, Berlin.

Gunn, D.M, 1980, The fate of king Saul: an interpretation of a biblical story, JSOT, suppl. ser. 14.

Hendel, R.S., 1995, 'Prophets, priests, and the efficacy of ritual', in D.P. Wright, D.N. Freedman \& A. Hurvitz (eds.), Pomegranates and golden bells: Studies in biblical, Jewish, and near eastern ritual, law and literature in honor of Jacob Milgrom, pp. 185-198, Eisenbrauns, Winona Lake, IN.

Jobling, D., 1998, 1 Samuel: Berit olam: Studies in Hebrew narrative \& poetry, The Liturgical, Collegeville, MI.

Kaiser, W.C., 1998, A history of Israel: From the bronze age through the Jewish wars, Broadman \& Holman, Nashville, TN.

Kasari, P., 2009, Nathan's promise in 2 Samuel 7 and related texts (PFES 97), Exegetical Society, Finnish, Helsinki.

Kitchen, K.A., 2003, On the reliability of the Old Testament, Eerdmans, Grand Rapids.

Klein, R.W., 1983, 1 Samuel (WBC 10), Word, Waco, TX.

Lambert, W.G., 1998, 'Kingship in ancient Mesopotamia', Day, 54-70.

Leick, G., 2003, The Babylon'ians: An introduction. Routledge, London.

Levinson, B.M., 2001, 'The reconceptualization of kingship in Deuteronomy and the deuteronomistic history's transformation of Torah', VT 51, 511-534.

Long, V.P., 1996, 'The art of biblical history', in M. Silva (ed.), Foundations of contemporary interpreation: six volumes in one, pp. 281-429, Zondervan, Grand Rapids.

Matthews, V.H., 2001, Social world of the Hebrew prophets, Hendrickson, Peabody, $\mathrm{MA}$

McCarter, P.K., 1980, 1 Samuel (AB 8), Doubleday, Garden City.

Miller, J.M., 1974, 'Saul's rise to power: some observations concerning 1 Sam 9:110:16, 10:26-11:15 and 13:2-14:46', CBQ 36, 157-174.

Miscall, P.D., 1986, 1 Samuel: a literary reading, Indiana University Press, Bloomington.

Orlinsky, H.M., 1975, 'Septuagint as holy writ and the philosophy of the translators'. HUCA 46, 89-114.

Parry, D.W. \& Ricks, S. D. (eds.), 1996, Current research and technological development on the Dead Sea scrolls: Conference on the texts from the Judean desert, Jerusalem, Brill, Leiden, 30 April 1995.

Pollock, S., 1999, Ancient Mesopotamia: the Eden that never was, Cambridge University Press, Cambridge.

Peterson, E.H., 1999, First and second Samuel, Westminster, Louisville.

Richter, W., 1970, Die sogenannten vorprophetischen Berufungsberichte. Eine literaturwissenschaftliche Studie zu 1 Sam. 9, 1-10, 16, Ex. 3f. und Ri. 6, 11b-17 (FRLANT 101), Vandenhoeck \& Ruprecht, Göttingen.

Rofé, A., 1982, 'The acts of Nahash according to 4QSama', IEJ 32(2-3), 129-133.

Schniedewind, W.M., 1999, Society and the promise to David: the reception history of 2 Samuel 7:1-17, Oxford University Press, New York.

Smith, S.T., 1997, 'State and Empire in the middle and new kingdoms', in J. Lustig (ed.), Anthropology and Egyptology: a developing dialogue (MMA 8), pp. 66-89, Sheffield Academic Press, Sheffield.
Shello

Tov, E., 2001, Textual criticism of the Hebrew Bible, 2nd rev. edn., Fortress, Minneapolis. Van de Mieroop, M., 1997, The ancient Mesopotamian city, Clarendon, Oxford. Van Seters, J., 2009, The biblical saga of king David, Eisenbrauns, Winona Lake, IN.

Vriezen, T.C. \& Van der Woude, A.S. 2005, Ancient Israelite and early Jewish literature, transl. B. Doyle, Brill, Leiden.

Wenham, G.J., 2000, Story as Torah: reading the Old Testament ethically, T \& T Clark, Edinburgh. 